инновационной активности промышленных предприятий : автореф. на соискание ученой степени дисс. канд. экон. наук : спец. 08.00.05 «Розвитие продуктивных сил и региональная экономика» / О.В.Никитина. - Санкт-Петербург, 2007. - 24 с. 16. Словарь инновационных терминов [Электронный ресурс]. - Режим доступа: infosystems.ru/ library/slovar_ais_ 12l8/slovar_innovaci_l222.html. 17. Тарасенко I. O. Оцінка інноваційної активності підприємства в системі стратегічного управління / I. О. Тарасенко, О. М. Королько, К. С. Белявська // Актуальні проблеми економіки. - 2009. - № 9 (99). - С. 133-141.

УДК 378:37.01

Наталія Шульга

\title{
ПОБУДОВА МОДЕЛІ ТРИ-СУБ’ЄКТНИХ ВІДНОСИН В ОСВІТНЬОМУ ПРОЦЕСІ ВНЗ
}

Шульга Н. В. Побудова моделі три-суб’єктних відносин в освітньому процесі ВНЗ.

У статті побудовано модель три-суб’єктних відносин в освітньому процесі та охарактеризовано ії складники: суб’єкта, що навчає, суб’єкта, що навчається та суб’єкта, що визначає інформаційно-комунікаційне педагогічне середовище (IKПC). Як основні складники характеристик суб’єкта, який навчає та суб’єкта, який навчається виокремлено операційний, світоглядний та рефлексивний компоненти. Структуру ІКПС охарактеризовано за принципами побудови, особливостями організації та формами взаємодії елементів.

Ключові слова: система навчання, три-суб’єктна дидактика, модель освітнього процесу, суб’єктність, навчальне середовище.

Шульга Н. В. Построение модели три-субъектных отношений в образовательном процессе вуза.

В статье построена модель три-субъектных отношений в образовательном процессе и охарактеризованы ее составляющие: обучающий субъект, обучающийся субъект, субъект, определяющий информационно-коммуникационную педагогическую среду (ИКПС). В качестве основных составляющих характеристик обучающего и обучающегося субъектов, выделены операционная, мировоззренческая и рефлексивная компоненты. Структура ИКПС охарактеризована по принципам построения, особенностями организации и формам взаимодействия элементов.

Ключевые слова: система обучения, три-субъектная дидактика, модель образовательного процесса, субъектность, учебная среда.

Shulga N. V. The model of three-subject relations in the educational process of the university.

The model of three-subject relations in the educational process is represented in the article. Its components: the teaching subject, the learning subject and the subject that determines the information and communication learning environment (ICLE) have been characterized. The main characteristics of teaching and learning subjects are operating, worldview and reflective components. ICLE structure is defined according to the communication strategy, organization features and forms of elements interaction.

Key words: education, three-subject didactics, a model of the educational process, subjectivity, learning environment. 
На сучасному етапі в еволюції людства відіграють значну роль глобальні процеси, що характеризуються стійкими суперечностями: між глобальним та локальним, духовним та матеріальним, загальним та індивідуальним, традиціями та сучасністю, конкуренцією та рівністю можливостей, необмеженим розширенням знань та обмеженими можливостями людини їх засвоїти. У цей період, на думку В. Кременя, особлива відповідальність лягає на систему освіти, яка має бути побудованою так, щоб зберегти духовно-культурні цінності людини та ствердити нові, сформувати творчу особистість, імперативи якої структурують реальність, перетворюючи світ із «хаосу» на «космос». Освітні програми повинні бути спрямованими не тільки на збільшення матеріальних, технічних чи духовних статків суспільства загалом, а й на розширення індивідуальних можливостей здійснювати той спосіб життя, що є пріоритетним для кожного члена соціуму [9]. Отже, на перший план у педагогічному процесі виходить суб’єкт навчання як самоактуалізована творча особистість, людина успіху, автор свого життя.

Специфіка процесів, які відбуваються в сучасних освітніх системах, полягає в тому, що на новітньому етапі розвитку людства виникла нагальна потреба переходу від жорстких, авторитарних форм навчального процесу до таких, що забезпечують навчання у спілкуванні, коли ролі студента та викладача перебувають у певному стані рівноваги, коли студент розуміє, що він прийшов отримати знання, а викладач - що він прийшов ділитися знаннями (а не повчати), коли кожний, хто бере участь у навчальній діяльності є унікальним, цікавим та значимим для навколишніх, активним та повноправним партнером [6 та ін.].

Розвиток освітньої системи залежить від значної кількості чинників, що зумовлюють еволюцію зв’язків між їі елементами до три-суб’єктних відносин, що передбачають упровадження в освітній процес (крім викладача та студента)- інформаційнокомунікаційного педагогічного середовища як третього активного рівноцінного суб'єкта [7; 11].

На думку Л. Петухової, три-суб’єктна дидактика $є$ одним із напрямів «педагогічної науки про найбільш загальні закономірності, принципи та засоби організації навчання, що забезпечує свідоме та міцне засвоєння системи знань, умінь і навичок у межах рівноправних взаємин учня (студента), учителя (викладача) та інформаційно-комунікаційного педагогічного середовища» [8]. У науковому дослідженні [11] автори доводять, що надання суб’єктних властивостей педагогічному середовищу не викликає суперечностей із філософським тлумаченням терміну «суб’єкт», що визначається як той, хто пізнає на вищому рівні предметно-практичної активності, цілісності, системності, автономності, творчості та $є$ носієм змін в інших людях і в самому собі. Оскільки суб’єкт «інформаційно-комунікаційне педагогічне середовище» містить компоненти, які передбачають не тільки технології, але й людські ресурси, що сприяють постійним змінам та оновленню формованого освітнього середовища, визначають його динаміку та вектор розвитку.

Метою статті є побудова моделі три-суб’єктних відносин в освітньому процесі вищих начальних закладів.

Першим суб’ єктом три-суб’єктної моделі освітньої системи є суб'єкт, який навчає викладач, основне завдання якого полягає не тільки i не стільки в постачанні, ретранслюванні знань, а в розробленні та використанні ефективних технологій навчання, які забезпечать здобуття необхідних студентам професійних умінь та навичок. Основними функціями викладача в такій взаємодії є функції посередника, інструктора, наставника, менеджера, який допомагає студентам розвинути здатності до пошуку, систематизації та аналізу інформації, віднайти свій шлях в інформаційному лабіринті знань. Суб’єктність 
викладача в освітньому процесі визначає його здатність до засвоєння, оволодіння та здійснення активної самостійної педагогічної діяльності, зміни педагогічної дійсності, інноваційних, креативних та прогресивних перетворень як у самому собі, так і в студентах та, взагалі, в педагогічному процесі [7, 10 та ін.].

Як основні складники характеристики викладача-суб'єкта освітнього процесу виокремимо операційний, світоглядний та рефлексивний компоненти [3 та ін.].

Операційний компонент моделі викладача включає в себе систему професійних знань, умінь та навичок, що відповідають вимогам професійної діяльності, функціям і обов'язкам, які закріплені в кваліфікаційній характеристиці. Особливості зазначеної системи полягають в тому, що вона:

- визначається особливою взаємодією між педагогом, студентом та освітнім середовищем, зумовленою як об’єктивними, так і суб’єктивними чинниками;

- потребує сформованості академічних, перцептивних, мовних, експресивних, організаторських, комунікативних якостей;

- здійснюється на основі гносеологічної, аксіологічної, творчої, комунікативної особистісних характеристик викладача.

Світоглядний компонент характеризується динамічною системою особистісних якостей, які визначають суб’єкта педагогічного процесу як унікальну, неповторну індивідуальність, що $є$ пріоритетною домінантою суспільного буття. Її особливості полягають в:

- усвідомленні педагогічного середовища як сучасного соціо- та полікультурного простору, у якому здійснюються гуманістично-спрямована соціальна взаємодія;

- сформованості професійно-особистісної готовності до гуманізації освітнього середовища, що сприяє розвитку міжособистісної толерантності учасників навчального процесу, їх устремлінь до співпраці та взаєморозуміння;

- активній участі у процесі створення освітнього середовища як простору духовного, етичного, естетичного, інтелектуального розвитку його суб’єктів;

- прагненні постійно співвідносити власну діяльність, коригувати дії, наміри та інтереси з діяльністю, потребами та інтересами інших суб’єктів педагогічного процесу.

Рефлексивний компонент - це складний психологічний феномен, що виявляється у здатності викладача формувати власну активну позицію щодо своєї діяльності та до самого себе як її суб’ єкта з метою критичного аналізу, обміркування та оцінювання ефективності, а також задля визначення оптимальних шляхів розвитку студентів у педагогічному процесі. Потреба в самоосвіті та здатність до неї сприяють формуванню системи розвинених, гнучких професійних знань і мислення, збагачують «Я-концепцію» педагога, забезпечують успішне розв’язання нестандартних, ускладнених нових професійних завдань.

Наступним суб'єктом у три-суб'єктній моделі навчального процесу є суб'єкт, що навчається - студент, що є членом особливої соціально-демографічної групи, до основних функцій якої належать: а) сприйняття матеріальних та духовних цінностей, напрацьованих суспільством на попередніх етапах розвитку; б) аналіз та оцінювання сучасного соціального буття; в) продукування нових форм розвитку суспільства. Саме тому в сучасному освітньому процесі змінилося ставлення до студента, який із пасивного спостерігача перетворюється на активного учасника, навіть співучасника, співавтора освітньої діяльності [2; 7].

У характеристиці студента - суб’єкта педагогічного процесу виокремимо також три компоненти: операційний, світоглядний та рефлексивний. 
Операційний компонент розкриває умови формування системи знань, умінь, навичок та необхідних способів дій, які сприяють контрольованому засвоєнню когнітивного, професійного та соціального досвіду. Характерні особливості розглядуваного компонента [1; 2]:

- суб’єктність студента, яка виражається через рівень активності, автономності, креативності в педагогічному процесі, що відображають його здатність до швидкої адаптації в освітній ситуації, саморегуляції, творчого ставлення до навчальної діяльності, самостійності, відповідальності, ініціативності та розуміння власної відповідальності за створення умов для свого розвитку;

- основні риси студента як суб’єкта навчальної діяльності - його вміння самостійно визначати цілі та приймати рішення в ситуації вибору; здатність до усвідомлення та прийняття задач навчальної діяльності, спроможність їх самостійно визначати; володіння орієнтовними основами діяльності; потреба в регулюванні власної поведінки та діяльності у відповідності до прийнятих задач; здатність усвідомлено оцінювати результати своєї діяльності та вносити до неї корективи;

- засвоєння навчальної інформації та необхідних практичних навичок здійснюється на основі підготовки до майбутньої професійної діяльності;

- навчальний процес відбувається в кілька стадій: початкова стадія - стадія адаптації до навчання у вищому навчальному закладі; друга стадія- ідентифікація 3 вимогами навчальної та навчально-професійної діяльності; третя стадія - самореалізація в освітньому процесі на основі взаємозв’язку з зовнішніми педагогічними впливами; четверта стадія самопроектування професійного становлення.

Характеристика світоглядного компонента, що визначає сформованість системи поглядів, знань, переконань, власної життєвої філософії, яка спирається на засвоєну раніше систему знань і здатність до абстрактно-теоретичного мислення полягає в тому, що світогляд студента, як одного з суб’єктів три-суб’єктної дидактики:

- у сучасних умовах формується під впливом глобальної суперечності між потребою в цілісному, внутрішньо несуперечливому світогляді та складністю його формування через наявність множинності світоглядів;

- є найбільш складною синтетичною формою духовного сприйняття дійсності, що містить філософські, економічні, політичні, соціологічні, моральні, естетичні, релігійні, наукові та ін. переконання;

- $є$ виявом самосвідомості, що визначає самооцінку власної індивідуальності, поведінки, якостей, рис, а також характеризує особливості взаємодії зі світом.

Рефлексивний компонент визначає сукупність інтелектуальних умінь студента суб’єкта освітньої системи, що процесуально пов’язані 3 самоспостереженням, інтроспекцією, ретроспекцією, спрямовані на усвідомлення та розв’язання професійних та суспільних задач, співставлення та узагальнення власної діяльності та надають можливість сформувати цілісне уявлення про світ, про знання, цілі, зміст, форми, способи та засоби власної діяльності, здатність до критичної самооцінки власної діяльності в минулому, сучасному та майбутньому часі.

Третім суб'єктом навчального процесу є суб'єкт, що визначає інформаційнокомунікаційне педагогічне середовище [7; 8; 11], який може бути охарактеризовано як «сукупність знанієвих, технологічних і ментальних сутностей, які в синхронній інтеграції забезпечують якісне оволодіння системою відповідних знань» [11]. Структуру третього 
суб’єкту освітньої системи охарактеризуємо за принципами побудови середовища, особливостями його організації та формами взаємодії елементів.

Принципи побудови інформаційно-комунікаційного педагогічного середовища (IКПС) зорієнтовані на розвиток особливостей, здібностей, індивідуальності, особистості того, хто навчається; на розкриття педагогічного, особистісного, творчого потенціалу того, хто навчає; на розширення предметних, методичних, інформаційних, програмних, технічних можливостей середовища, у якому відбувається процес навчання [6; 11 та ін.]. Виокремимо три групи принципів побудови IКПС: Принцип самості передбачає створення в навчальному середовищі умов для розвитку особистості як суб’єкта діяльності та соціальних відносин, розкритті всіх притаманних їй властивостей, індивідуальних здібностей та інтересів, активізації внутрішніх резервів, здатності до саморозвитку та формування професійної компетентності; Принцип взаємності визначає необхідність організації навчального процесу в ІКПС на основі комунікації його суб’єктів; Принцип проектування - конструювання ІКПС має відбуватися на основі глибоких знань щодо цілей, змісту, технологій навчання, різноманітних технологічних елементів, засобів навчання та способах їх поєднання. Одночасно, освітній процес повинен бути гнучким, варіативним, багатофакторним, спрямованим на забезпечення умов для виявлення та структурування суб'єктивного досвіду, розвиток індивідуальних здібностей, соціалізацію кожного його учасника.

Організація ІКПС має відповідати вимогам сучасної освіти та сприяти досягненню наступних цілей [7 та ін.]: забезпечення якісної, конкурентоспроможної освіти відповідно до вимог інноваційного сталого розвитку соціально-економічного середовища; забезпечення особистісного розвитку людини згідно з їі індивідуальними здібностями та потребами; підготовка суб’ єктів навчального процесу до життєдіяльності в інформаційному суспільстві 3 глобальним ринком праці; створення умов для реалізації потенційних можливостей викладачів та студентів, для задоволення їх освітніх потреб, розвитку соціальної та професійної мобільності; забезпечення сприятливого мікроклімату всередині ІКПС, що характеризується відкритістю, довірою та підтримкою; формування інформаційнокомунікаційної культури, мотиваційної, когнітивної та організаційної готовності до інноваційної діяльності.

Взаємодія між суб’єктами ІКПС є формою організації їх сумісної діяльності, що грунтується на співробітництві, спрямована на досягнення спільних цілей та результатів, в процесі якої відбувається обмін діями, необхідними для розвитку та становлення особистості, ґенези індивідуальності [4 та ін.]. Сумісна діяльність між суб’єктами середовища відбувається на трьох рівнях [4]: рівні міжособистісного взаємовпливу, що передбачає духовний саморозвиток, засвоєння цінностей, поєднання внутрішніх світів; рівні міжособистісної взаємодії, спрямованої на засвоєння групових норм, ролей, схем діяльності; рівні співробітництва, що забезпечує такий рівень взаємодії, на якому суб'єкти освітнього процесу поєднуються в єдину функціональну систему із взаємозалежними та взаємообумовленими зв'язками.

Засобом взаємодії суб’єктів навчального середовище виступає спілкування, що є проекцією взаємовідносин між ними та визначає поле культурних і навчальних смислів, текстів, діалогів, на основі яких відбувається становлення особистісної позиції суб’єктів навчання.

Загальний результат діяльності досягається через взаємодію з об’єктом навчання, що визначається як об’єктивний світ, який пізнається та перетворюється у відповідності до потреб суб’єктів навчальної діяльності та у відповідності до законів і закономірностей 
існування даного світу [2, 9 та ін.]. Отже, суб’єкти освітньої системи (і викладач, і студент), можуть виступати також і об'єктами навчального середовища, оскільки їх самих можна вивчати (їх досвід, знання, поведінку, психологічні особливості). Тому, суб’єкт-суб’єктна взаємодія в педагогічному процесі має досить розмиті границі.

Модель три-суб’єктних відносин в освітньому процесі вищих навчальних закладів може бути побудованою як взаємодія трьох суб’єктів (суб’єкту, який навчає; суб’єкту, який навчається та суб’єкту, що визначає інформаційно-комунікаційного педагогічного середовища), яка відбувається на основі спілкування (що визначається як засіб взаємодії) та спрямована на пізнання об’єктивного світу (як об’єкту навчання). Результатом вказаної взаємодії є формування індивіда, здатного (в процесі виконання професійних, суспільних обов’язків, та в особистому бутті) до перетворення об'єктивної реальності на суб'єктивну та спрямованого на самопізнання, самореалізацію, самовдосконалення. Графічне представлення побудованої моделі наведено на рис. 1.

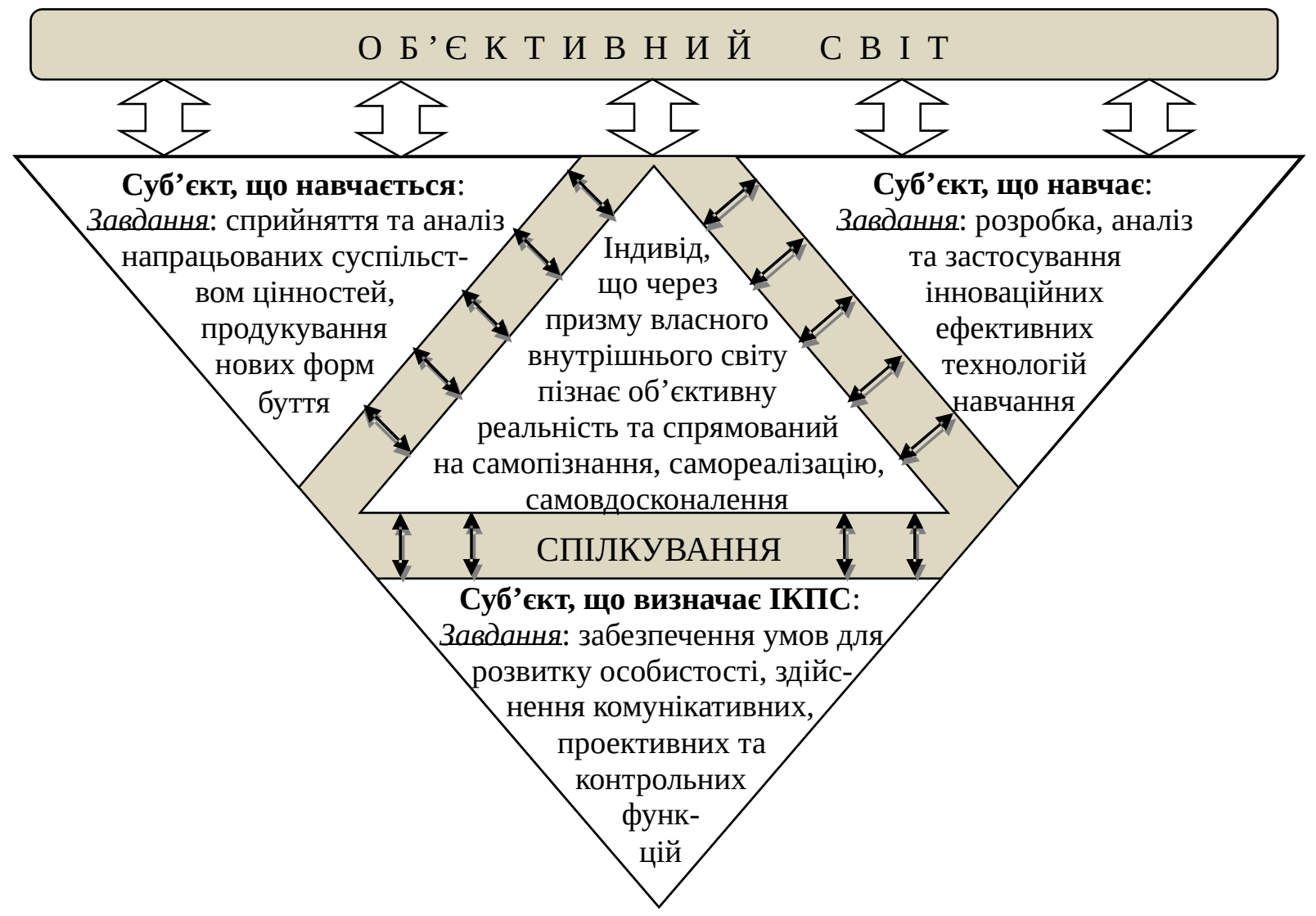

Рис. 1. Модель три-суб’єктних відносин в освітньому процесі

\section{Література}

1. Белошицкий А. В. Становление субъектности студентов в образовательном процессе вуза / А. В. Белошицкий, И. Ф. Бережная // Педагогика - 2006. - № 5. - С. 60-61. 2. Васильев П. В. К вопросу о субъектах и объектах педагогического процесса / П. В. Васильев // Известия Южного федерального университета. Педагогические науки. 2013. - № 2. - С. 19-26. 3. Дєніжна С. О. Рефлексія у контексті розвитку інноваційної культури педагога / C. О. Дєніжна // Науковий вісник Національного університету біоресурсів і природокористування України. - 2009. - Вип. 143. - С. 83-90. 4. Линник Е. О. Сущностная характеристика понятия «субъект-субъектное взаимодействие»: психолого- 
педагогический аспект / Е. О. Линник // Инновационные образовательные технологии. 2013. - № 4 (36). - С. 48-54. 5. Мачуліна I. I. Викладач вищої школи в умовах модернізації освіти: побудова теоретичної моделі / I. I. Мачуліна // Преподаватель как субъект и объект образовательного процесса. Век XXI : [материалы Международной науч.-практ. конф., Харьков, 1 февр. 2012 г.] : в 2 ч. - Харьков: Изд-во НУА. - 2012. - Ч. 2. - С. 23-29. 6. Мушинская О. В. Психологические особенности личности в структуре педагогических способностей преподавателя / О.В.Мушинская // Преподаватель как субъект и объект образовательного процесса. Век XXI : [материалы Международной науч.-практ. конф., Харьков, 1 февр. 2012 г.] : в 2 ч. - Харьков: Изд-во НУА. - 2012. - Ч. 2. - С. 35-43. 7. Онищенко I. Особливості професійної підготовки майбутнього вчителя початкових класів у моделі трисуб'єктних відносин / Ірина Онищенко // Психолого-педагогічні проблеми сільської школи. - 2013. - Вип. 47. - С. 31-37. 8. Петухова Л. Є. Теоретико-методичні засади формування інформатичних компетентностей майбутніх учителів початкових класів : дис. на здобуття наук. ступеня доктора пед. наук : 13.00.04 / Петухова Л. Є. - Херсон, 2009. - 564 с.

9. Попов А. Открытое образование: философия и технологии / Александр Попов. - Москва : УРСС, 2013. - 256 с. 10. Слободчиков В. И. Психологические условия введения студентов в профессию педагога / В. И. Слободчиков, Н. А. Исаева // Вопросы психологии. - 1996. № 4. - С. 72-80. 11. Співаковський О. В. До оцінювання взаємодії у моделі «Викладач студент - середовище» / О.В.Співаковський, Л. Є. Петухова, Н. А. Воропай // Наука i освіта. - 2011. - № 4/С. - С. 401-405. 